Received $\quad 30.10 .2017$

Reviewed 13.04 .2018

Accepted 09.07.2018

A - study design

B - data collection

C - statistical analysis

D - data interpretation

E - manuscript preparation

$\mathbf{F}$ - literature search

\title{
Quality of Hamadian groundwater table of the continental tertiary of Wadi Mehiya in Tindouf province (South-West of Algeria)
}

\author{
Mohamed F. BEKKOUCH ${ }^{\mathrm{ABCDEF} \bowtie}$, Ahlam ZANAGUI ${ }^{\text {BCDEF }}$
}

\begin{abstract}
University Center of Tindouf, Faculty of Earth Sciences, 37000 Tindouf, Algeria; e-mail: bekk_fouzi@yahoo.fr,
\end{abstract} zanagui_ahlam@yahoo.fr

For citation: Bekkouch M.F., Zanagui A. 2018. Quality of Hamadian groundwater table of the continental tertiary of Wadi Mehiya in Tindouf province (South-West of Algeria). Journal of Water and Land Development. No. 39 p. 3-9. DOI: 10.2478/jwld2018-0053.

\begin{abstract}
The Hamadian groundwater table ensures water supply for the agricultural perimeter of Wadi Mehiya region in the North-East of Tindouf city. In order to determine the behaviour of this groundwater table, a piezometric map have been realized, followed by physicochemical analyses to assess the chemical facies, the suitability of this water for irrigation and drinking purposes, as well as its vulnerability to different pollutants. This groundwater table is essentially composed of fine to coarse and clayey sands, surmounted by a silicified limestone slab. It is a free groundwater table with a thickness of 18 to $99 \mathrm{~m}$. The sampling has been done in June 2010. Then, the physicochemical analyses have been performed on 7 samples taken from 7 boreholes. The piezometric study proved that the flow of groundwater table follows a North-East to South-West direction, towards the Sebkha of Tindouf. The graphic representation of chemical facies, using Piper and SchoellerBerkaloff diagrams, reveals that the water of Wadi Mehiya contains mainly magnesium sulphate. The graphical representation of irrigation water quality, using Wilcox diagram, revealed an acceptable quality with a high salinity. Moreover, this water is potable with hard-mineralized character. Nitrates contamination has been also noted, which is a logical result of the excessive use of chemical fertilizers.
\end{abstract}

Key words: Hamadi groundwater table, irrigation, quality, salinity, vulnerability, Wadi Mehiya

\section{INTRODUCTION}

This study aims to present the main hydrogeological and hydrochemical characteristics of the Hamadian groundwater table, feeding the agricultural perimeter of Wadi Mehiya, situated in North of Tindouf city [HAISSOUNE 1998]. The chemical analysis of water is an important complement for the hydrogeological study of the groundwater table, consequently for water resources management. It provides a database on the aquifer environment, the host nature, the supplying and circulation zones in the groundwater table, and the concentration of water pollutants [BENKHLIFA, BELABBES 2017].

The groundwater table of Wadi Mehiya, located in the Hamada zone, in the North of Tindouf city belongs to the continental tertiary. It deposits in horizontal layers, the Hamada is essentially composed of fine yellow sandstone with marly cement. This groundwater table covers all the northern region of the province. The reservoir is formed mainly by fine to coarse sand and clay sand, with thickness of about $10 \mathrm{~m}$ near the Sebkha of "Abdallah", reaching a hundred meters in the basin centre, next to the zone of "Hassi el naga" [HAISSOUNE 1998].

The groundwater table is currently solicited by dozens of boreholes. It is known in the regions of "Hassi Ammar" (low flow), "Wadi Zez" (low flow), "Wadi Mehiya", "Graret el Harth", "Hassi el Naga" (low flow), "Oum el-Assel" (low flow), and the West of the sub-basin of "Hassi Khebbi" (flow 2-10 $\mathrm{dm}^{3} \cdot \mathrm{s}^{-1}$ ). The Hamadian formation has no Hydrogeological interest on the axis linking the region of "Fort Lotfi" to "Hassi Khebbi". The water mineralization varies between 0.9 and $3 \mathrm{~g} \cdot \mathrm{dm}^{-3}$ [KASBAOUI, AlLAOUI 2017]. 


\section{MATERIAL AND METHODS}

\section{PHYSICAL FRAME OF THE STUDIED AREA}

Tindouf province is located in the South-West of Algeria near the Algerian-Moroccan borders, $1900 \mathrm{~km}$ from Algiers and between $26-28^{\circ} \mathrm{N}$ and 6-9 $9^{\circ} \mathrm{W}$ (Fig. 1). The Hamada of Tindouf has local names such as Hamada of "Arouieda" and Hamada of "Ed Douakel". It is limited in the North by the Atlas piedmont, in the East and West by the outcrops of old formations, and in the South by a cliff rising on Paleozoic formations. The surface of the Hamadian is tabular with small undulations; the shores range from $420 \mathrm{~m}$ to $480 \mathrm{~m}$. Many Sebkha are settled in the depressions, but the main one is the Sebkha of Tindouf. It extends along a West-East line of more than $100 \mathrm{~km}$ long and $20 \mathrm{~km}$ wide [ZANAGUI 2016].

The studied area is located in the North-East of Tindouf city, bordered to the North by "Grarret el Harth", to the West by Hamada of "Merkala", to the South by "Wadi Nebka", and to the East by "Wadi el Maa" (Fig. 1). The geographical coordinates of the region of Wadi Mehiya are $27^{\circ} 47^{\prime} 39^{\prime \prime} \mathrm{N}$ and $8^{\circ} 4^{\prime} 53^{\prime \prime} \mathrm{W}$.

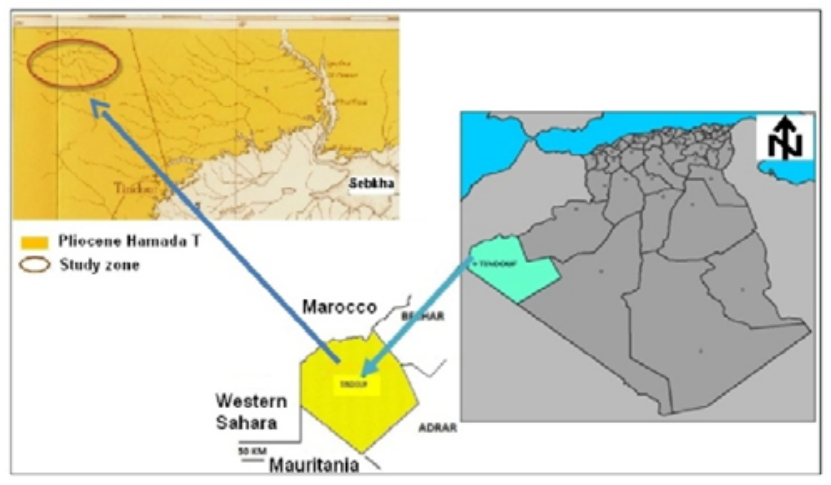

Fig. 1. Localization of the study area; source: own elaboration

The studied region is characterized by a dry and arid climate with average interannual (average of 9 years, 2007-2016) rainfall of $25.9 \mathrm{~mm}$ and high evapotranspiration rates (Fig. 2) [RAGGADI, BouNAIM 2015].

On the geological plan, the basin of Tindouf is a vast syncline, East-West oriented [HANI et al. 2003] and a surface of $180.000 \mathrm{~km}^{2}$ [ANRH 2010].

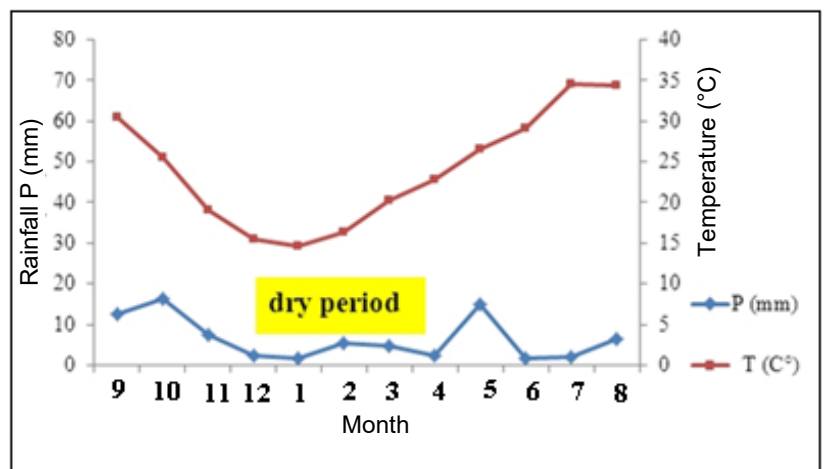

Fig. 2. Ombrothermic diagram of Gaussen of the Tindouf province (2007-2016); source: own elaboration
The centre of the syncline is occupied by Mio-Pliocene deposits (Hamada) reposed on Paleozoic formations (Carboniferous, Devonian, Gothlandian, Ordovician and Cambrian), in the South and South-East, the territory consists of volcanic and metamorphic of Yetti-Eglab massif rocks.

According to the geological data of the water drillings (OM2, OM3, OM5) the Hamadian groundwater table consists mainly of fine to coarse sands and clay sands, the whole is surmounted by a slab of silicified limestone, also is a free tablecloth their thickness from 18 to 99 m (Fig. 3).
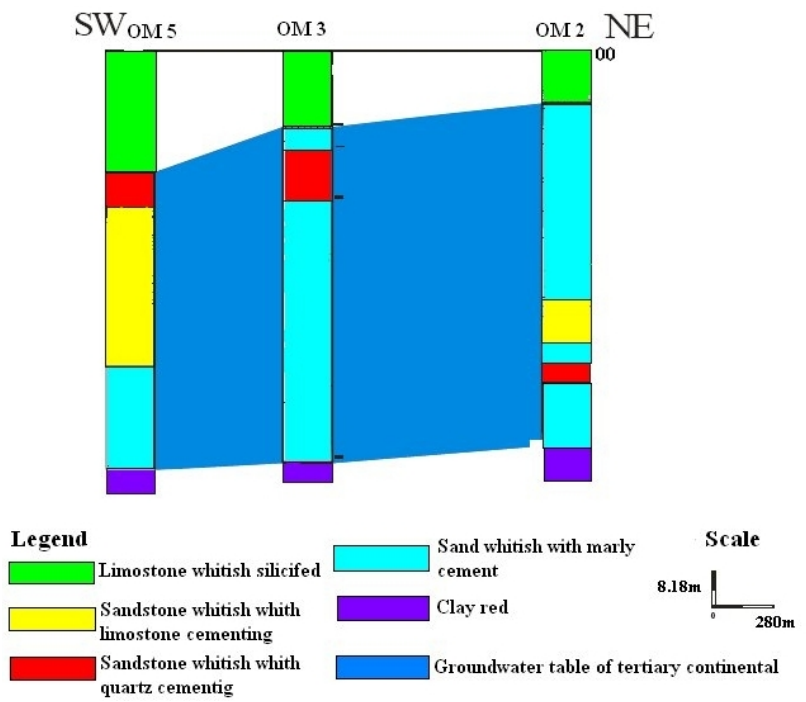

Fig. 3. Correlation of boreholes located in the groundwater table of Wadi Mehiya; source: own elaboration

On the hydrogeological plan, the piezometric map (Fig. 4) reveals that groundwater flow follows a NW-SE direction with a cone of depressions on the water drillings (OM5, OM3) proving an overexploitation of the groundwater table.

The isotopic study allowed to define three groups of water, according to the tritium content: old water (before 1952) (from 0 to $8.3 \mathrm{UT}$ ), relatively recent water (from 8.3 to $16.6 \mathrm{UT}$ ), and recent water (more than 16.6 UT). The combination of these groups of water permits to identify six families of water according to the water salinity and tritium content [HANI et al. 2003; MELLOUL 1995].

The Hamadian groundwater table is marked by the presence of all water families, which indicates the influence of evaporation and local supply on the water chemistry.

The supply axis is characterized by a transition zone between the Hamada of Tindouf, supplying the Hamadian groundwater table by precipitation. The Sebkha of Tindouf represents the main outlet of the groundwater table [HANI et al. 2003]. We notice a hydraulic continuity between the Hamadian formations and the underlying layers of Visean limestones. The supply of the latter is governed by the precipitations on the Hamadian formations, which can be in hydraulic continuity with the limestones over a broad band West-East oriented [HANI et al. 2003]. It comes also from the inputs of outcrop zones of the Atlas aquifers [Progress Sarl Annaba 1999]. 


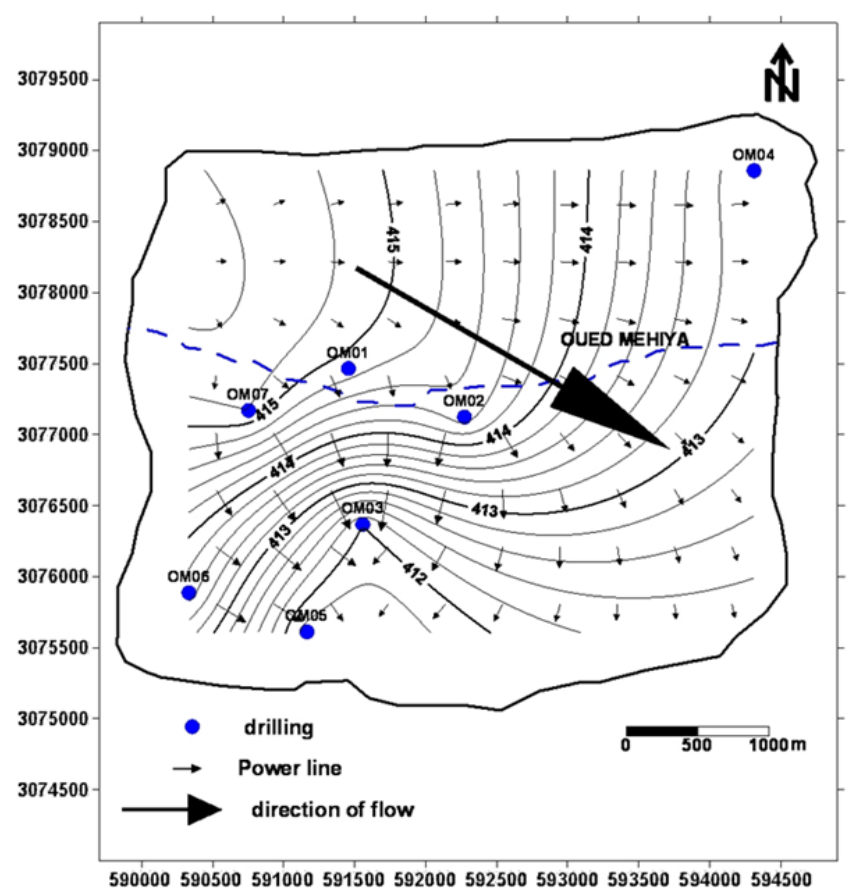

Fig. 4. Piezometric map of Wadi Mehiya basin (June, 2010); source: own study

\section{SAMPLING AND ANALYSIS}

The sampling has been done in June 2010 and the physicochemical analyses have been performed on 7 samples taken from 7 boreholes (Fig. 5), on the laboratory of physico chemical analysis of the National Water Resources Agency (Fr. Agence Nationale des Ressources Hydrauliques - ANRH) in Adrar city, following the French Standardization Association standards (Fr. Association Française de Normalisation - AFNOR) [AFNOR 1997].

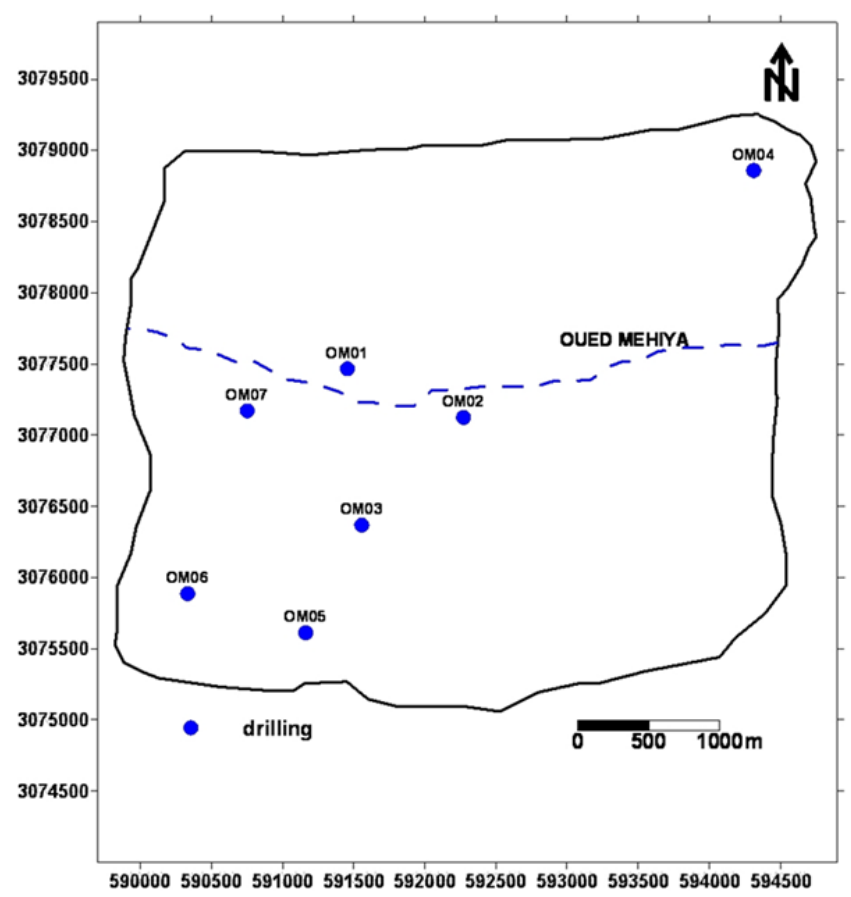

Fig. 5. Inventory map of sampling points; OM1-OM7 as in Fig. 4; source: own elaboration
The assay has focused on the following major elements: cations: $\mathrm{Ca}^{2+}, \mathrm{Mg}^{2+}, \mathrm{Na}^{+}$and $\mathrm{K}^{+}$anions: $\mathrm{Cl}^{-}, \mathrm{SO}_{4}{ }^{2-}$ and $\mathrm{HCO}_{3}^{-}$; physicochemical parameters: $\mathrm{pH}$, electrical conductivity $(E C)$, dry residue $(D R)$ and temperature; total mineralization: $\mathrm{SiO}_{2}^{-}$, total hardness $(T H)$, total alkalinity $(T A C)$ and alkalinity $(T A)$; pollution elements: $\mathrm{NH}_{4}{ }^{+}, \mathrm{NO}_{2}^{-}$, $\mathrm{NO}_{3}{ }^{-}$, and $\mathrm{PO}_{4}{ }^{3-}$. The material and methods used in the study are presented in (Tab. 1).

Table 1. Equipment and methods for water analysis

\begin{tabular}{|l|c|c|c|}
\hline \multicolumn{1}{|c|}{ Parameter } & $\begin{array}{c}\text { Measurement by } \\
\text { electrochemical } \\
\text { portable probe }\end{array}$ & $\begin{array}{c}\text { Photometry } \\
\text { (spectrometry) }\end{array}$ & $\begin{array}{c}\text { Titration or } \\
\text { colorimetry }\end{array}$ \\
\hline $\mathrm{pH}$ & $\mathrm{X}$ & & \\
\hline Conductivity & $\mathrm{X}$ & & \\
\hline Chlorides & & & $\mathrm{X}$ \\
\hline Alkalinity & & & $\mathrm{X}$ \\
\hline Organic. phosphates & & $\mathrm{X}$ & \\
\hline Ammonium & & $\mathrm{X}$ & \\
\hline Sulphates & & $\mathrm{X}$ & \\
\hline Nitrates / nitrites & & $\mathrm{X}$ & \\
\hline Calcium & & $\mathrm{X}$ & \\
\hline Magnesium & & $\mathrm{X}$ & \\
\hline Sodium & & $\mathrm{X}$ & $\mathrm{X}$ \\
\hline Potassium & & & \\
\hline Hardness & & & \\
\hline Silica & & & \\
\hline
\end{tabular}

Source: own elaboration.

\section{RESULTS AND DISCUSSION}

\section{PARAMETERS FOR IRRIGATION}

The results of physico-chemical analysis of the Hamadian groundwater table revealed the parameters used to estimate the quality of irrigation water (Tab. 2). Among these parameters, we note the salinity expressed by the electrical conductivity $(E C)$, the residual sodium carbonate (RSC), the percentage of $\mathrm{Na}$, the $S A R$ (sodium absorption ratio), and the chlorides toxicity [GOUAIDIA et al. 2013].

The $E C$ values reached $2470 \mu \mathrm{S} \cdot \mathrm{cm}^{-1}$, which corresponds to an average salinity due to the arid climate producing a high evaporation, increasing then the concentration of the soil solution [CHEVERRY, ROBERT 1998]. The average conductivity is $2180 \mu \mathrm{S} \cdot \mathrm{cm}^{-1}$ (Tab. 2) which proves the acceptable quality of the groundwater table of Wadi Mehiya. However, the average $S A R$ is $3.03 \mathrm{meq} \cdot \mathrm{dm}^{-3}$, referring to low to medium sodization risk. The chlorides come probably from the percolation through the salty ground none of the analysed samples has reached the concentration $10 \mathrm{meq} \cdot \mathrm{dm}^{-3}$, which is the maximal concentration admissible for the plants.

Table 2. Statistical parameters of some groundwater variables of the Hamadian groundwater table of Wadi Mehiya (2010)

\begin{tabular}{|c|c|c|c|c|}
\hline \multirow{2}{*}{ Specification } & \multirow{2}{*}{$\begin{array}{c}E C \\
\mu \mathrm{S} \mathrm{cm}^{-1}\end{array}$} & SAR & $\mathrm{Cl}$ & $\% \mathrm{Na}$ \\
\hline & & \multicolumn{3}{|c|}{$\mathrm{meq} \cdot \mathrm{dm}^{-3}$} \\
\hline Min & 2040 & 2.38 & 6.72 & 29.45 \\
\hline Max & 2470 & 3.86 & 9.03 & 41.60 \\
\hline Average & 2180 & 3.03 & 7.51 & 35.70 \\
\hline
\end{tabular}

Source: own study. 


\section{CHEMICAL FACIES}

According to Piper diagram (Fig. 6), there is only one chemical facies which is the sulfated magnesian except for the sample No. OM2, where the facies is sulfated sodic. The origin of sulphates is the gypseous formation of the Sebkha of Tindouf due to the leaching of this formation by the water supplying the Hamadian groundwater table, from cracked limestones (roof of the water table) enriching the later with sulphates; while, the magnesium originates from the sandstone reservoir of the Hamadian water table [HAISSOUNE 1998].

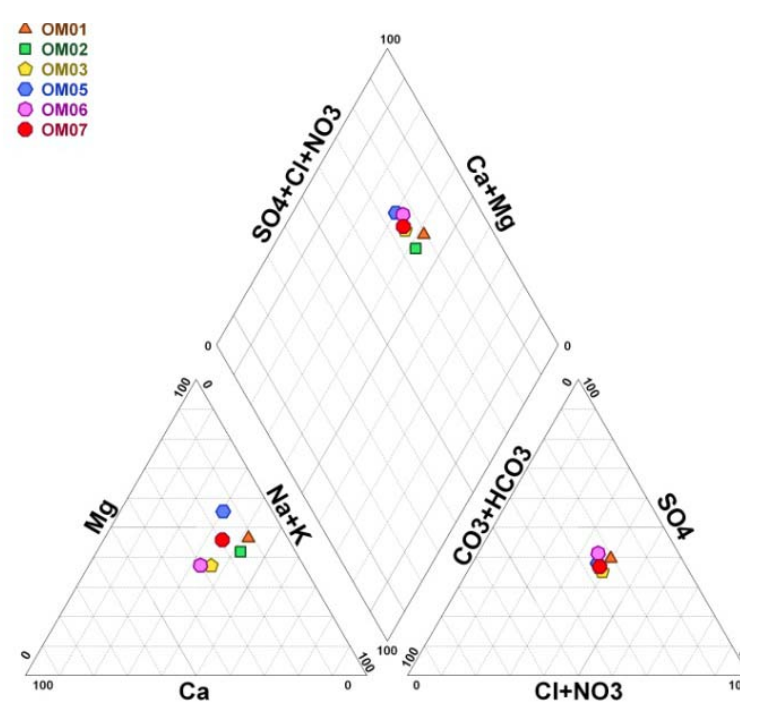

Fig. 6. Graphical representation of chemical facies (Piper diagram, June 2010); OM1-OM7 as in Fig. 4; source: own study

\section{WATER QUALITY FOR IRRIGATION}

Irrigation plays a dominant role in agriculture because of degrading water resources and variant distribution of the rainfalls. Farmers need to save water and make judicious use of it, especially during the dry season [HALIMI et al. 2017; ZARE et al. 2014]. When the concentration of soluble $\mathrm{Na}^{+}$ions in the soil is high, these ions replace the $\mathrm{Ca}^{2+}$ cations (basic exchanges) in the absorbing complex; this can be induced by salt-loaded water; this risk is determined by the measurement of sodium absorption ratio (SAR) [GOUAIDIA et al. 2013].

$$
S A R=(\mathrm{Na}+\mathrm{K}) / \sqrt{(\mathrm{Ca}+\mathrm{Mg}) / 2}
$$

For the same conductivity, the risk is even greater when the coefficient is higher.

After plotting all the water points on the Wilcox diagram (Fig. 7) and according to the electrical conductivity and the $S A R$, the water classes found are:

- C3S1 class designates water admissible in the irrigation of salt-tolerant crops, on well-drained soils, with good permeability, where the salinity should be controlled; the $\mathrm{C} 3 \mathrm{~S} 1$ class characterizes all boreholes except OM1;

- C4S1 class indicates mediocre highly mineralized water; suitable for the irrigation of certain crops with high salt tolerance on well-drained soils; the C4S1 class characterizes the OM boreholes.

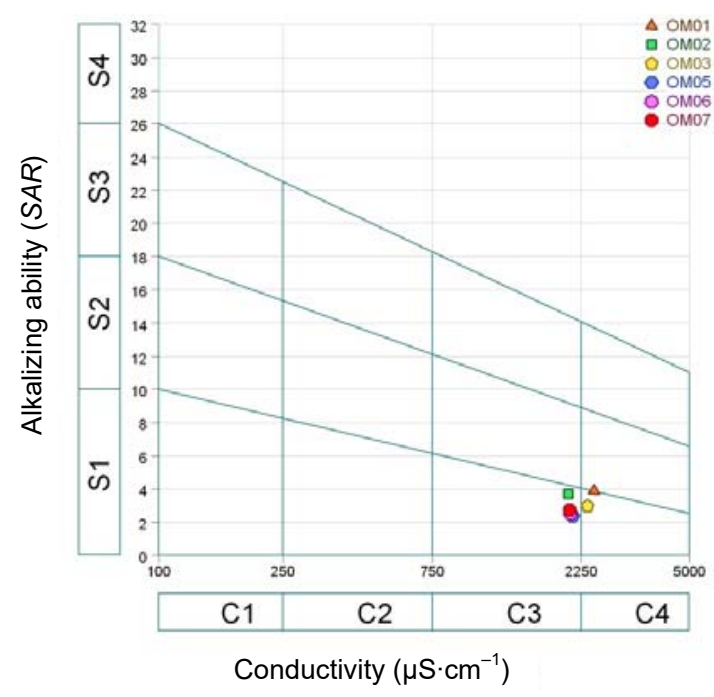

Fig. 7. Water quality according to Wilcox diagram (June, 2010); source: own study

It is noted that when the chemical facies of agricultural water is chlorinated, the $S A R$ often minimizes the risk of water sodization and alkalinisation. Therefore, the residual sodium carbonate (RSC) has been used as another parameter to evaluate the quality of irrigation water in this study.

The determination of $R S C$ is performed according to the following equation:

$$
R S C=\left(\mathrm{CO}_{3}{ }^{-}+\mathrm{HCO}_{3}^{-}\right)-\left(\mathrm{Ca}^{2+}+\mathrm{Mg}^{2+}\right)
$$

Following the $R S C$, the water is divided into two classes:

- type $01(R S C>0)$, presenting a risk of degradation of the soils physical properties, by sodization;

- type $02(R S C<0)$, with a low risk of degradation compared to the previous type [GOUAIDIA et al. 2013; MARLET, JOB 2006; SUMNER 1993].

The results obtained proved that the water of the Hamadian groundwater table of Wadi Mehiya belongs to the type 02 (Tab. 3).

Table 3. Water types according to residual sodium carbonate (RSC)

\begin{tabular}{|c|c|c|}
\hline Specification & RSC & Type \\
\hline Min & -10.36 & 2 \\
\hline Max & -7.66 & 2 \\
\hline Average & -9.02 & 2 \\
\hline$\%$ & \multicolumn{2}{|c|}{100} \\
\hline
\end{tabular}

Source: own study.

\section{WATER POTABILITY AND VULNERABILITY OF THE WATER TABLE}

\section{Concentration in physical parameters}

\section{- $\mathbf{p H}$}

The water acidity itself does not pose any problem for consumer health. However, acidic water distributed through pipeline system may present an indirect risk to the health of misinformed or careless consumer. 
Acidic water is aggressive (corrosive) and can release the constitutive metals of the pipes i.e. iron, copper, lead, nickel, chromium and zinc [HANON, ROUELLE 2011; KAHOUL, TOUHAMI 2014].

The local and international standards for drinking water quality recommend a $\mathrm{pH}$ between 6.5 and 8.5 [Journal... 1993; WHO 1994]. Regarding these standards, the analysed water has a normal $\mathrm{pH}$, ranging from 6.15 to 7.51 study (Tab. 4).

\section{- Conductivity}

The conductivity measurement permits to determine the degree of water mineralization, since most of the water dissolved materials are present as electrically charged ions. According to the conductivity, the water classification is done as follows: conductivity equal to $0.05 \mu \mathrm{S} \cdot \mathrm{cm}^{-1}$, demineralized water; conductivity from 10 to $80 \mu \mathrm{S} \cdot \mathrm{cm}^{-1}$ : rainwater; conductivity of $80-100 \mu \mathrm{S} \cdot \mathrm{cm}^{-1}$ : water with little mineralization; conductivity from 300 to $500 \mu \mathrm{S} \cdot \mathrm{cm}^{-1}$. moderately mineralized water; conductivity from 1000 to $3000 \mu \mathrm{S} \cdot \mathrm{cm}^{-1}$ : saline water; conductivity more than 3000 $\mu \mathrm{S} \cdot \mathrm{cm}^{-1}$ : seawater [RODIER et al. 2009]. The conductivity of Wadi Mehiya groundwater table ranges from 2040 to $2470 \mu \mathrm{S} \cdot \mathrm{cm}^{-1}$ (Tab. 4); thus, it belongs to saline water. It is also mineralized with mineralization degree ranging between 1300 and $1600 \mathrm{mg} \cdot \mathrm{dm}^{-3}$; (Tab. 4) but without exceeding the local norms $\left(2000 \mathrm{mg} \cdot \mathrm{dm}^{-3}\right)$. The origin of this salinity and mineralization is the leaching of the crossed carbonated and gypseous formations in addition to the impact of evaporitic gypsiferous formations the Sebkha of Tindouf.

Table 4. Statistical parameters of some physical variables of the groundwater of Hamadian groundwater table (2010)

\begin{tabular}{|c|c|c|c|}
\hline Specification & $\mathrm{pH}$ & $\begin{array}{c}E C \\
\mu \mathrm{S} \cdot \mathrm{cm}^{-1}\end{array}$ & $\begin{array}{c}\text { Dry residues at } 100^{\circ} \mathrm{C} \\
\mathrm{mg} \cdot \mathrm{dm}^{-3}\end{array}$ \\
\hline Min & 6.15 & 2040 & 1300 \\
\hline Max & 7.51 & 2470 & 1600 \\
\hline Average & 6.92 & 2180 & 1415 \\
\hline
\end{tabular}

Source: own study.

\section{Concentration of chemical parameters}

\section{- Calcium}

Calcium is generally the dominant element in drinking water where its content varies mainly according to the nature of the crossed ground (limestone or gypsum) [RODIER et al. 2009]. The undesirable organoleptic and aesthetic characteristics of the drinking water, following the presence of calcium, come from its contribution to the hardness [AWWA 1990]. The calcium content of the water analysed (Tab. 5) is lower than the maximum permissible concentration $\left(200 \mathrm{mg} \cdot \mathrm{dm}^{-3}\right)$, established by local standards [KAHOUL, TOUHAMI 2014; NA 1992] for drinking water.

\section{- Chlorides}

Chloride is very common element in nature where its content in water is highly variable and mainly related to the nature of the crossed ground. According to the local standards for drinking water quality, chlorides must have a concentration of less than $500 \mathrm{mg} \cdot \mathrm{dm}^{-3}$ in drinking water [KAHOUL, TOUHAMI 2014; NA 1992].
The analysis revealed normal quantities of chlorides in Wadi Mehiya groundwater table, ranging from 250 to 320 $\mathrm{mg} \cdot \mathrm{dm}^{-3}$ (Tab. 5); similar results were noted in many previous studies. The chlorides have no adverse effect on the consumer health, even with a high concentration in drinking water. This is because the chloride concentration in the body is regulated by a complex system involving both the nervous and the hormonal systems. Even after the absorption of high quantities of chlorides, the chloride balance is maintained, especially by the excretion of the excess in the urine.

\section{- Hardness}

The results of water hardness measurements of the Wadi Mehiya groundwater table (Tab. 5) revealed values exceeding the local standards that require a maximum permissible concentration of $500 \mathrm{mg} \cdot \mathrm{dm}^{-3}$; this high degree of hardness have no impact on consumer health, since a number of epidemiological studies performed in Canada, England, Australia and the United States respectively proved an inverse statistical correlation between the hardness of drinking water and certain types of cardiovascular diseases.

Table 5. Statistical parameters of some chemical variables of the groundwater of Hamadian groundwater table (2010).

\begin{tabular}{|c|r|r|r|r|c|c|c|c|c|c|c|}
\hline \multirow{2}{*}{$\begin{array}{c}\text { Specifi- } \\
\text { cation }\end{array}$} & $\mathrm{Ca}^{2+}$ & $\mathrm{Mg}^{2+}$ & $\mathrm{Na}^{+}+\mathrm{K}^{+}$ & $\mathrm{Cl}^{-}$ & $\mathrm{SO}_{4}^{2-}$ & $\mathrm{HCO}_{3}^{-}$ & $\mathrm{SiO}_{2}^{-}$ & $\mathrm{TH}$ & $\mathrm{TAC}$ \\
\cline { 2 - 11 } $\mathrm{mg} \cdot \mathrm{dm}^{-3}$ \\
\hline Min & 66 & 96 & 161 & 250 & 365 & 290 & 17 & 650 & 240 \\
\hline Max & 124 & 154 & 246 & 320 & 482 & 360 & 30 & 780 & 300 \\
\hline Average & 89 & 121 & 192 & 266 & 405 & 329 & 23 & 700 & 270 \\
\hline
\end{tabular}

Explanations: $T H=$ alkalinity, $T A C=$ total alkalinity. Source: own study.

\section{Concentration in pollution parameters}

\section{- Nitrate}

Nitrates $\left(\mathrm{NO}_{3}{ }^{-}\right)$are common natural ions resulting mainly from the nitrogen oxidation by microorganisms in plants, soil and water. The sources of nitrates in water (particularly groundwater) are generally decomposed of animal and plant matter, agricultural fertilizers, manure, domestic sewage, and geological formations containing soluble nitrogenous compounds. According to the Algerian [Décret exécutif... 2011] and European standards [Council Directive... 1998], the nitrates concentration does not 50 $\mathrm{mg} \cdot \mathrm{dm}^{-3}$ in drinking water.

The analysed water has nitrates concentration varying between 3.20 and $70 \mathrm{mg} \cdot \mathrm{dm}^{-3}$ (Tab. 6), which refers to a contamination of the groundwater table, due to the excessive use of agricultural chemical fertilizers. Such a water has no impact on the health of infants under 6 months, but once reduced to nitrites, it can cause methemoglobinemia [L'HIRONDEL 1993].

Apart from nitrates, the groundwater table of Wadi Mehiya remains protected against pollution; due to its remoteness from the urban perimeter and industrial discharges.

According to concentration in the $\mathrm{NH}_{4}{ }^{+}, \mathrm{NO}_{2}{ }^{-}$and $\mathrm{PO}_{4}{ }^{3-}$ the groundwater table of Wadi Mehiya does not present a pollution (except at OM2 a small pollution with $\mathrm{NO}_{2}^{-}$). 
Table 6. Statistical parameters of some pollution variables of the groundwater of Hamadian groundwater table (2010)

\begin{tabular}{|c|c|c|c|c|}
\hline \multirow{2}{*}{ Specification } & $\mathrm{NH}_{4}{ }^{+}$ & $\mathrm{NO}_{2}{ }^{-}$ & $\mathrm{NO}_{3}{ }^{-}$ & $\mathrm{PO}_{4}{ }^{3-}$ \\
\cline { 2 - 5 } & \multicolumn{4}{|c|}{$\mathrm{mg} \cdot \mathrm{dm}^{-3}$} \\
\hline Min & 0 & 0 & 3.20 & 0.03 \\
\hline Max & 0.03 & 0.21 & 70 & 0.40 \\
\hline Average & 0.016 & 0.08 & 58.3 & 0.14 \\
\hline
\end{tabular}

Source: own study.

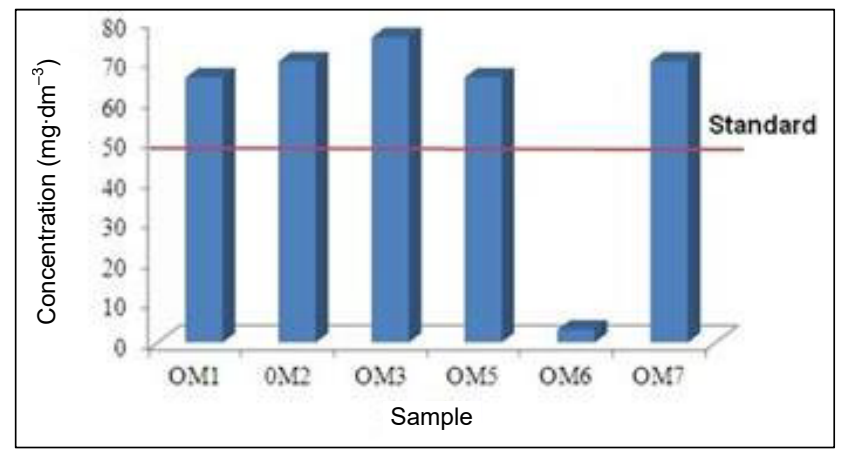

Fig. 8. Nitrate concentration in the Wadi Mehiya groundwater table; OM1-OM7 as in Fig. 4; source: own study

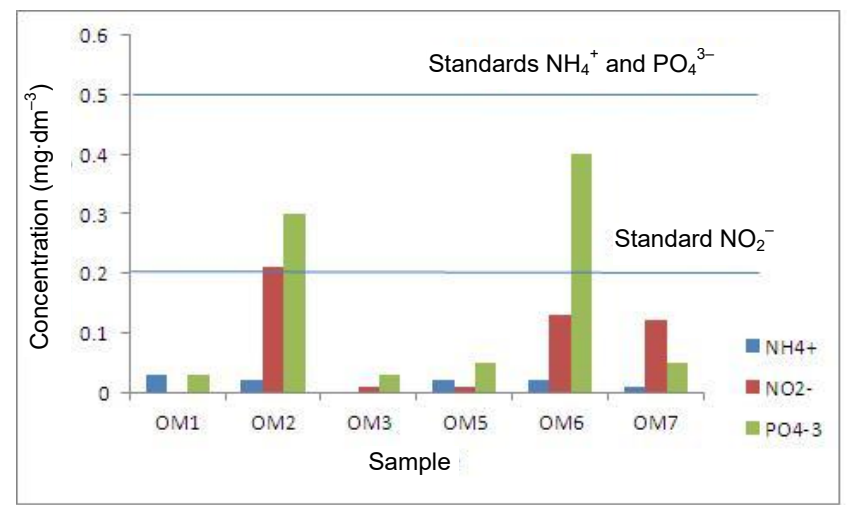

Fig. 9. $\mathrm{NH}_{4}{ }^{+}, \mathrm{NO}_{2}{ }^{-}$and $\mathrm{PO}_{4}{ }^{3-}$ concentration in the Wadi Mehiya groundwater table; OM1-OM7 as in Fig. 4; source: own study

\section{GENERALE CONCLUSION}

The evaluation of the quality of groundwater used for irrigation in the agricultural zone of Wadi Mehiya has a high necessity, due to many environmental troubles in this region such as drought and the unavailability of surface water, added the high water demand for the agricultural activities. The analysis of the salinity parameters has allowed the evaluation of the quality of these waters. Using conventional methods, this assessment revealed the presence of water with medium salinity and acceptable quality for irrigation. The water salinity is the result of many factors, namely:

- aquifer material, with an heterogeneous lithology, composed essentially of clays, limestone, sandstone, and gypsiferous and evaporitic formations of the Sebkha of Tindouf rich in $\mathrm{Cl}^{-}, \mathrm{Na}^{+}, \mathrm{SO}_{4}{ }^{2-}$, and $\mathrm{Ca}^{2+}$;

- climatic conditions, characterized by an arid and dry climate, during the whole, inducing an important evapotranspiration;
- the studied groundwater presents a low risk of alkalization and can be used for irrigation due to its average SAR value $\left(5 \mathrm{meq} \cdot \mathrm{dm}^{-3}\right)$.

In term of water quality for human consumption, almost all the parameters analysed meet both national and international standards, regarding the drinking water quality. The excessive mineralization and the hardness are due to the lithological nature of the reservoir and the impact of the Sebkha. In the face of the problem of excessive nitrates, known by their adverse effects on health, it is strongly recommended to minimize the use of agricultural chemical fertilizers. According to concentration in the ammonium, nitrite and phosphate, the groundwater table of Wadi Mehiya does not present pollution.

To sum up, the water of the Hamadian groundwater table of Wadi Mehiya can be considered potable only after treatment, while it is admissible for irrigation. However, the low water flow does not cover the demands of the agricultural perimeter, requiring then other researches to quantify the reserve and a good exploitation management.

\section{REFERENCES}

AFNOR 1997. Qualité de l'eau : analyse biochimique et biologique, analyse microbiologique, textes réglementaires. T. 1. Terminologie, échantillonnage et évaluation des méthodes [Water quality: biochemical and biological analysis, microbiological analysis, regulatory texts. T. 1. Terminology, sampling and evaluation of methods]. $2^{\text {nd }}$ ed. Paris, France. Association française de normalisation pp. 376.

ANRH 2010. Rapport hydrochimique de Tindouf [Hydrochemical report of Tindouf]. Adrar. Agence nationale de ressources hydrique p. 24-26.

AWWA 1990. Water quality and handbook of community water supplies. $4^{\text {th }}$ ed. Ed. F.W. Pontius. American Water Works Association. New York, NY. McGraw-Hill p. 224-227.

BEATSON C.G. 1978. Methemoglobinemia-nitrates in drinking water. Environmental Health. Vol. 86 p. 31-33.

Benkhlifa F., BelabBes A. 2017. Etude hydrogéologique et hydrochimique de la nappe du viséen supérieur - Tindouf [Hydrogeological and hydrochemical study of the upper viséen water table - Tindouf]. Master thesis. Centre universitaire de Tindouf pp. 45.

Cheverry C., Robert M. 1998. La dégradation des sols irrigués et de la ressource en eau : une menace pour l'avenir de l'agriculture et pour l'environnement des pays au sud de la méditerranée [Degradation of irrigated soils and water resources: A threat to the future of agriculture and the environment in south Mediterranean countries]. Etude et Gestion des Sols. Vol. 5. No. 4 p. 217-226.

Council Directive 98/83/EC on water quality of 3 November 1998 on the quality of water intended for human consumption. OJ L 330.

Décret exécutif $\mathrm{n}^{\circ} 11-219$ du 10 Rajab 1432 correspondant au 12 juin 2011 fixant les objectifs de qualité des eaux superficielles et souterraines destinées à l'alimentation en eau des populations [Executive Decree No. 11-219 of 10 Rajab 1432 corresponding to June 12, 2011 setting the quality objectives for surface water and groundwater intended for the water supply of populations].

Gouaidia L., Guefaifia O., Boudoukha A., Hemila Ml. 2013. Evaluation de la salinité des eaux souterraines utilisées en irrigation et risques de dégradation des sols : Exemple de la plaine de Meskiana, nord-est algérien [Evaluation of the 
salinity of groundwater used in irrigation and soil degradation risks: Example of the Meskiana's plain, Northeastern Algeria]. Geo-Eco-Trop. Vol. 37. No. 1 p. 81-92.

HAISSOUNE D. 1998. Contribution à l'étude hydrogéologie de la nappe Hamadienne de Tindouf [Contribution to the hydrogeology study of the Hamadian water table of Tindouf]. Mémoire fin d'étude, université d'Oran (thesis) pp. 36.

Halimi S., Rechachi H., Bahroun S., Mizane N.E., Daifallah T. 2017. Assessment of groundwater salinity and risk of soil degradation in Quaternary aquifer system. Example: Annaba plain, Algeria N-E. Journal of Water and Land Development. No. 36 p. 63. DOI 10.2478/jwld-2018-0006.

HANi A., DJABRi L., LALlahem S., MANIA J. 2003. Identification des axes d'écoulement souterrains dans les systèmes aquifères du bassin de Tindouf et des plaines d'Annaba-Bouteldja, Hydrology of lite Mediterranean and Semiarid Regions [Identification of the underground flow axes in the aquifer systems of the Tindouf's basin and the Annaba-Bouteldja plains, hydrology of the Mediterranean and semiarid regions]. Proceedings of an international symposium. Montpellier. April 2003. Ingénieur d'Affaires à l'International. IS Publication. No. 278 p. $125-126$.

HANON M., Rouelle A. 2011. Le pH de l'eau de distribution. En : Qualité des eaux distribuées par le réseau public en Wallonie [pH of the distribution water. In: Quality of the water distributed by the public network in Wallonia] [online]. [Access 15.06.2017]. Available at: http://environnement.wallonie.be/ de/eso/eau_distribution/\#3.4

Journal Officiel de la Republique Algerienne (JORA) 1993. $\mathrm{N}^{\circ} 46$ du 10 Juillet 1993, 7-12 [Official Journal of the Algerian Republic]. No. 46, July 10, 1993, 7-12.

Kahoul M., Touhami M. 2014. Evaluation de la qualité physico chimique des eaux de consommation de la ville d'Annaba (Algérie) [Evaluation of the physico-chemical quality of drinking water in the city of Annaba, Algeria]. Larhyss Journal. No. 19p. 129-138.

KasbaOui A., Allaoui A. 2017. Qualité et potabilité des eaux de la région de Tindouf [Water quality and potability of Tindouf Region]. Master Thesis. Centre universitaire de Tindouf pp. 44.

L'HiRONDEL J. 1993. Les méthémoglobinémies du nourrisson, Données nouvelles [Methemoglobinemia in infants, New data]. Cahiers de Nutrition et de Diététique. Vol. 28 p. 341349.

Marlet S., Job J.O. 2006. Processus et gestion de la salinité des sols. In: Traité d'irrigation [Process and management of soil salinity. In: Irrigation treatise]. Eds. J.R. Tiercelin, A. Vidal. $2^{\text {nd }}$ ed. Paris. Tec and Doc Lavoisier p. 797-822.

Melloul A.J. 1995. Use of principal components analysis for studying deep aquifers with scarce data-application to the Nubian sandstone aquifer, Egypt and Israel. Hydrogeology Journal. Vol. 3. Iss. 2 p. 19-39.

NA 6360. Les spécifications physicochimiques de l'eau [The physicochemical specifications of water]. Ed. Ianor pp. 49.

Progress Sarl-Annaba 1999. Etude de rénovation du champ captant de Hassi-Abdallah (Wilaya de Tindouf) (Rapport de synthèse, mission 1, phase A et B [Study of renovation of the capture field of Hassi-Abdallah (Wilaya of Tindouf). Summary report, mission 1 , phase $\mathrm{A}$ and $\mathrm{B}]$.

Raggadi O., Bounaim I. 2015. Comportement de la nappe Hamadienne au niveau de périmètre agricole de Grarret El Harth [Behavior of the Hamadian water table at Grarret El Harth agricultural area]. Master thesis. Centre universitaire de Tindouf pp. 30.

Rodier J., Legube B., Merlet N., Brunet R. 2009. L'analyse de l'eau [Water analysis]. 9 ed. Paris. Dunod. ISBN 9782100072460 pp. 1600.

SuMNER M.E. 1993. Sodicsoils - new perspectives. Australian Journal of Soil Research. Vol. 31 p. 683-750.

WHO 1994. Quality guidelines for drinking water. World Health Organization p. 19-187.

ZANAGUI A. 2016. Contribution à l'étude hydrogéologique et hydrochimique de la nappe du bassin versant d'Oued Mehiya [Contribution to the hydrogeological and hydrochemical study of the water table of the Wadi Mehiya watershed]. Master thesis. Centre universitaire de Tindouf pp. 30.

Zare N., Khaledian M., Mailhol J.-C. 2014. Using water and agrochemicals in the soil, crop and Vadose Environment (WAVE) model to interpret nitrogen balance and soil water reserve under different tillage managements. Journal of Water and Land Development. No. 22 p. 33-39. DOI 10.2478/jwld2014-0020.

\section{Mohamed F. BEKKOUCH, Ahlam ZANAGUI \\ Jakość wód gruntowych poziomu Hamadi w utworach kontynentalnego trzeciorzędu w zasięgu rzeki Mehiya, prowincja Tindouf w południowo-zachodniej Algierii}

\section{STRESZCZENIE}

Poziom wodonośny Hamadi zapewnia dostawy wody dla rolniczych terenów regionu Wadi Mehiya na północny wschód od miasta Tindouf. W celu określenia właściwości poziomu wodonośnego wykonano mapę piezometryczną, a następnie przeprowadzono analizy fizyczne i chemiczne do oceny składu wody, jej przydatności do nawodnień i zaopatrzenia ludności w wodę pitną, jak również podatności zasobów na różne zanieczyszczenia. Poziom wodonośny znajduje się w warstwie gliniastego piasku o zmiennym uziarnieniu podścielonego warstwą krzemionkowo-wapienną. Jest to poziom o swobodnym zwierciadle wody o miąższości od 18 do 99 m. Próbki wody pobrano w czerwcu 2010 r. Analizy fizyczne i chemiczne wykonano w 7 próbkach pobranych z 7 odwiertów. Badania piezometryczne wykazały, że woda gruntowa płynie z północnego wschodu na południowy zachód w kierunku Sebkha k. Tindouf. Graficzna prezentacja wyników z wykorzystaniem diagramów Pipera i Shoellera-Berkaloffa dowodzi, że w składzie chemicznym wody Wadi Mehiya dominuje siarczan magnezu. Graficzne przedstawienie jakości wody do nawodnień wg diagramu Wilcoxa wykazało akceptowalną jakość z dużym zasoleniem. Ta wysoce zmineralizowana woda nadaje się do celów spożywczych. Zanotowano także zanieczyszczenie azotanami, co jest skutkiem nadmiernego stosowania nawozów mineralnych.

Słowa kluczowe: jakość, nawodnienia, podatność, poziom wodonośny Hamadi, Wadi Mehiya, zasolenie 